\title{
1. Introduction: the basic paradigms and constitutional framework of intellectual property law
}

\section{Foreword: the Mosaic and the Fabric}

Patent, trademark and copyright: each of the fundamental paradigms of intellectual property law (hence, IP law) is governed by a highly specific legislative framework in terms of subject matter, function, governing principles, etc. This specificity, whose characteristic elements will be examined later, should not however let us lose sight of the 'underlying' shared fabric of economic and constitutional-type common denominators, which in turn reflect common historical and institutional roots.

Indeed, born of the dual, political and economic, revolution that crowned the Age of Enlightenment, modern IP law essentially reflects a legal framework governing the policies of industrial and commercial development and innovation based on the right of free economic initiative and free market competition. In previous centuries - from the age of the guilds through to the mercantile system - this policy was basically grounded on corporative and/or individual ${ }^{1}$ privileges, concessions and limited access, typical of a command economy.

A careful consideration of that framework, shaped by its revolutionary background, is essential to a systemically rewardingly reconstruction of the basic features of intellectual property rights (hence, IPRs), as well as of the ways the latter are intertwined with and 'alloyed' by the rules governing competition, namely antitrust and unfair competition law. In particular, such consideration will highlight how all the various IP paradigms, beyond their different normative features, are based on a dialectic relationship between 'property' (exclusive individual rights) and 'freedom' (of each individual to

1 For example, as early as the Venetian patents of the mid-15th century individual privileges often conflicted (and indeed were granted for that very purpose) with the sectoral monopolies enjoyed by corporations, thereby also opening up the way to the subsequent equality of law sanctioned by the industrial revolution(s). See further the bibliographical notes to this chapter. 
access the market and to operate there under conditions of equal treatment under law - thereby also indirectly promoting the freedom of choice of consumers). ${ }^{2}$

\section{From Paris and Berne to Marrakech: IP's Basic Paradigms}

\section{The classic dualism between patents and copyright, and its evolution}

The diversification of the fundamental paradigms of IP law has its historical roots above all in a series of regulations introduced to specifically protect the new results of creative activity. Here, the normative models embraced by the new liberal-inspired legal systems ${ }^{3}$ highlighted a fundamental dualism rooted in the different nature and function of the 'subject matter' protected. On the one hand, practical-utilitarian innovation; on the other, new works of merely intellectual fruition (aesthetics in the broadest sense).

The distinction (which the classic nomenclature reflected by distinguishing industrial from intellectual property in a strict sense) was consecrated in the great universal Conventions of Paris and Berne ${ }^{4}$ which took place at the end of the 1800s, in the wake of the widespread expansion in production and trade produced by the first and already incipient second industrial revolution ${ }^{5}$ (from steam power to electro-mechanics to early telecommunication systems). These Conventions sought to give a rational and essentially homogeneous structure (in formal accordance with the principle of 'assimilation' between nationals and foreigners $)^{6}$ to transnational business relations involving the exploitation

2 On the distinction between freedom of competition, as an individual constitutionally protected right (article 41 of the Italian Constitution) and the concept of effective competition as a method of market functioning in an objective sense, see $\mathrm{M}$. LIBERTINI, Tutela della concorrenza nella costituzione italiana, in Giur. Cost., 2005, p. 1429.

3 Models were still undifferentiated in precursory laws like the Statute of Anne of 1710. See the reconstruction of L. MoscATI, Un 'memorandum' di John Locke tra censorship e copyright, in Rassegna forense, 2005, p. 603. For more details see the bibliographical notes.

4 Paris Union Convention (PUC) for the protection of industrial property, signed 20 March 1883, last revised: Stockholm, 14 July 1967; Berne Convention (BC) for the protection of artistic and literary works, signed 4 May 1886, last revised: Paris, 24 July 1971.

5 For references on the historical connection between those Conventions and the great industrial expositions of the second half of the 19th century, see the bibliographical notes.

6 I say 'formal accordance' since the 'foreigners' granted rights had to be citizens of, or at least operating in, contracting Member States: thus, the substantial inspiration of said Conventions lay rather in a 'sentiment de réciprocité', as F. MAINIÉ, Nouveau Traité des brevets d'invention, II, 1896, 919, remarked about an earlier Convention (Berne, 1844). 
of intangible assets that had become strategic levers of competition and hence a new source of wealth of nations.

Thus, on the one hand, the Paris Convention referred to utilitarian innovations, that is, technology, using the general paradigm of patent for industrial invention and utility model. On the other hand, the Berne Convention referred to creations designed for mere intellectual enjoyment (the first Berne catalogue was actually limited to 'literary and artistic works'), ${ }^{7}$ using the sharply different paradigm of droit d'auteur, that is, substantially copyright (see below, Chapter 3).

This dualism (whose most visible sign is the different term of protection of the exclusive rights granted) reflects deep material phenomenal and economic differences between innovation aimed at satisfying material demands and innovation designed to meet purely intellectual and aesthetic needs. This topic will be examined in more depth in Chapter 3, analysing the various differences between the patent and the copyright paradigms.

This classic dualism (also hinted in article I, section 8, clause 8, of the US Constitution, promoting the 'progress of science and useful arts') was formally recomposed in the Agreement on Trade-related Aspects of Intellectual Property Rights (TRIPs), signed in Marrakech on 15 April 1994 and that entered into force on 1 January 1995. Compliance with the TRIPs is a condition of membership of the World Trade Organization, which was established by a broader agreement on international trade, supplanting the General Agreement on Tariffs and Trade (GATT), which was signed and took effect on the same date.

The TRIPs represents the new 'universal convention' which, at the end of the second millennium and in the midst of the new industrial revolution marked by information technology, bio- and nano-engineering, has redefined the rules on intellectual property around minimum standards of protection that essentially reflect - as we shall see in more depth in the Appendix - established regulatory models of industrially advanced countries. ${ }^{8}$ As mentioned before, the Agreement formally brings together in one single convention, under a common core of 'fundamental principles' (articles 1-8: see article 7 on the 'Objectives') the classical regulatory dichotomy between industrial and

7 See below Chapter 3 for the subsequent opening up of copyright to various creations that also or in some cases solely served a practical function. The key example here is computer software.

8 It is no secret that the TRIPs was strongly advocated by the most industrialised nations, first and foremost the US, even with direct intense diplomatic support (as confirmed, ex multis, in the enlightening essay by M.P. RYAN, Knowledge Diplomacy: Global Competition and the Politics of Intellectual Property, Washington, DC, 1998). 
intellectual property, aiming to express on a global scale a basically common regulatory framework of international trade relations linked to the exploitation of intangible goods as a source of competitive advantage. ${ }^{9}$

Moreover, even apart from its (formal) bridging, that classic dualism had become increasingly strained in modern times due to a move towards normative overlaps and/or cumulation of different types of protection (for example, laws on trademarks, design, copyright insisting on the shapes of products) and the growth in 'hybrid' paradigms that have become a feature of some special regulations regarding certain industrial sectors. For example, the protection of software is afforded by both patent and copyright law. Similarly, industrial design can claim protection under four different regimes (registered model, copyright, shape trademark, passing-off: see Chapters 3 and 4).

In general terms, the most relevant indicator (and instrument) of the tendency for overlaps and hybridisation is the 'expansion' of copyright to creations such as computer software and databases (typical information technology tools) or utilitarian products of industrial design (see below, Chapter 3).

\section{The (expanded) protection of trademarks}

A third and markedly different paradigm (of which the duration of exclusive rights - here potentially unlimited - is again the most visible feature) characterises a further series of rules that make up the IPR family. I refer to those that concern the protection of distinctive signs: rules on firms' names, signboards, and above all trademarks (of products or services), the latter being the fundamental paradigm of the subject matter. Within this general framework, one can also place the similar but distinct rules on geographic denominations of origin, owing to the underlying competition dynamics (see below, Chapter 4).

The classic mission of trademark regulation is to protect business identity (and de facto connected goodwill) from a risk of confusion: a risk inherent in a competitive and hence unlimitedly pluralistic market. By 'identity', I mean not only the 'paternity' (the firm of origin) of the product (or service) involved, but also the specificity of the products offered for sale. The two profiles are reflected in the distinction between 'general' and 'product' trademarks: the former aimed at distinguishing Ferrero from other manufacturers, the latter Mon Chéri from other chocolate-coated cherries.

Distinctive signs, and trademarks in particular, protect against the risk of confusion arising when both manufacturers or retailers guarantee to consumers (below, Chapter 4) that each product is associated with its true origin. This ensures that supply meets demand without consumers' choices

9 Nuno Pires De Carvalho, The TRIPs Regime of Patent Rights, London, 2002, pp. 24 et seq. 
being sidetracked or interfered with. As such, one must add, the protection concerns the entire range of goods - products and services - offered on the market. That said, it is all too obvious that trademark protection is especially decisive to the market entry and progress of new products, for which clear 'recognition' is a more pressing need than for mature products already well known to consumers.

Again, in trademark regulation, as we shall see (Chapter 4), the classic model based on the sole protection of the distinguishing function of the trademark (essentially circumscribed to an area of identical or similar goods, i.e. focused on the risk of confusion) has 'evolved'. ${ }^{10}$ In order to encompass the possible so-called 'advertising' value (hence, 'selling power') of signs, especially renowned ones, this legal protection has been expanded beyond its classical limits, enforcing the rightholder's exclusive power even in relation to 'non-similar' (thus non-confusable) goods.

Patent, copyright and trademark regulations are supplemented by further rules aimed at protecting businesses against a series of attacks by competitors that cannot be specifically withstood by the rules protecting IPRs. In particular, this is true of two sets of norms concerning competition.

First, most relevant for the actual shaping of IPRs-related powers is antitrust law, aimed at protecting the market's competitive framework as such. Second, is the law against unfair competition, based on the principles of article 10-bis of the Paris Convention, and aimed at protecting individual competitors against professional misbehaviour. (Apart from these, and albeit beyond the scope of this work, mention must also be made of provisions rooted in public law, which, in addition to their primary aim of safeguarding the public interest, protect firms against misconduct such as boycotts, industrial espionage, commercial fraud and misleading advertising, and similar business malpractices; hence often overlapping with the rules against unfair competition.)

The relationship between these sets of norms and the discipline of IPRs will be examined later in this chapter at section 6 and more extensively in Chapter 5 .

\section{The Firm as the Central Reference of IP Law}

The structural common denominator of IPRs (more precisely: of their economic profiles) is their central focus on the role and interests of firms rather than individuals (authors, inventors) - engaged in producing and placing on the market products or services made of the 'non-material' fruits of

10 I set this in brackets because of the negative effects of that development on the very dynamics of innovation: below Chapter 4 . 
human ingenuity - inventions, works of art - and marked by same firms' distinctive signs, etc. This is indeed the 'pole' around which the triple-tiered framework of IP regulations described above (as well as the rules on unfair competition) is essentially built. Its direct constitutional reference is the principle of freedom of enterprise with which one must compare, and 'harmonise' (below, following section) other non-entrepreneurial (at least in an individual sense) social and economic interests, also of constitutional rank.

In the next paragraph I shall give an overview of the 'other' interests that enter with ever increasing frequency and momentum (at times, even with prevailing status: think, for example, of the right of a researcher to freely use a patented invention for experimental purposes), ${ }^{11}$ into the overall contemporary constitutional framework of IP law. I wish now to emphasise the fact that the central focus of the discipline - even of the very 'structure' of IPRs - still lies ${ }^{12}$ with the role of the individual firms actually or potentially engaged in the production or distribution of (goods or services incorporating, and distinguished by) those same 'non-material' assets. This assumption is confirmed by a multiplicity of indications, from both international and national sources of positive law.

For example, in the field of patents:

- the principle of non-patentability of inventions that are not capable of direct industrial applications (articles 52(2) and 57 of the European Patent Convention (EPC));

- the frequent provisions entrenched in many national systems, as for example in Germany and Italy (but with a significant pro-labour differentiation in UK as concerns inventions not made in the execution of one's contractual or fiduciary duties ${ }^{13}$ ), that accrue to the firm the right to the economic exploitation of employees' inventions;

11 The same can be said for the affirmation of the rights of third parties or the community as a whole inspired either by humanitarian reasons and by the need for information: below Chapters 2 and 3 .

12 It is possible that, in the future, the focus of IP law will extend to or even shift as advocated by various projects seeking to radically overhaul the system. See, for example, that of an international research group organised by the University of Stockholm called 'IP in Transition Research Programme', at http://www.atrip.org/ upload/files/activities/Parma2006/ Kur\%20AMENDMENT.pdf. Further references in Chapter 2, note 81 and in Appendix, note 13.

13 See section 39 of the UK Patent Act, as amended in 1977. For an in-depth analysis of the provision, including from a historical perspective, see W. CORNISH, Intellectual Property: Patents, Copyrights, Trademarks and Allied Rights, 2003, 264 et seq. On the point at issue, UK law seems substantially convergent with the approach adopted by the US Supreme Court in Dubilier (289 US 178 (1933)) 'where the contract of employment does not contemplate invention... the right of patent belongs to the employee'. 
- the 'working requirement', that is, the duty to proceed with the industrial implementation of inventions and utility models or be subject - to the direct advantage of other, competing, firms - to the imposition of non-voluntary licensing, or even the revocation of patent rights: see article 5 of the Paris Convention and articles 30 and 31 of the TRIPs Agreement.

In respect of trademarks, one need only refer, first of all, to their intrinsic purpose 'of distinguishing the goods and services of an undertaking from those of other undertakings' (article 15 of the TRIPs Agreement). So too for other signs, such as the firm's name (individual or corporate) distinguishing the undertaking's business, and for signboards distinguishing shops and other outlets. Think too of the rules on trademark licences, forfeiture through nonuse (that is, non-use 'in commerce'), extension of renowned signs' protection to 'not similar' fields of business, etc. (Chapter 4).

As far as copyright is concerned, the focus on the firm (as distinct, first of all, from the physical author) is generally more indirect but no less certain. In fact, in order to enjoy an affordable economic return from her work, the author thereof must normally assign her rights to a publisher that has the means and organisation suited to 'make up', reproduce and market for mass consumption the work itself, whether on a physical medium (book, CD, DVD etc.) or directly online via an electronic network. The concrete possibility for an author to directly exploit the work on her own exists (currently) basically only for unique works intended for private collections or galleries. And even in relation to the direct online diffusion of audiovisual works, especially when it relates to complex works to be 'set up', and distributed on a large scale, the so-called cultural industry is still the normally inescapable assignee, and actual 'market manager' of the rights originally vested in the author. ${ }^{14}$

In recognition of such a reality, copyright law expressly recognises the role of the firm in organising the preparation and commercial distribution of the work. Think, for example, of cinematographic works, where the right to economically exploit the rights of the film's co-authors is entrusted 'to those who organised the production of the work', that is, the producers (article 14bis of the Berne Convention). Also noteworthy are the so-called neighbouring rights of phono-record producers, radio and television broadcasters, etc. (more in Chapter 3).

14 The direct set-up and 'peer-to peer' transmission by authors, including users' own works ('used generated content') is certainly an increasingly interesting phenomenon, yet mostly circumscribed by technical and economic constraints on certain types of 'simpler', low-cost work (on this, more in Chapter 3). 
Finally, with regard to the related area of unfair competition, the focus on business undertakings is implicit in the very subject matter of the rules and is in any event expressly confirmed in the repeated reference in the Paris Convention to the risk of creating confusion with or discrediting 'the establishment, the goods, or the industrial or commercial activities, of a competitor' (article 10-bis(3)(1) and (2)).

\section{Rationale of that Centrality}

This typical, 'structural' focus of IP law on (individual) firms' activity and interests, reflects a basic economic rationale.

In particular, as regards technological innovation, the protection of results of $R \& D$ activities through patents plays a central and specific role in recovering the costs and compensating the efforts and investments of the firm itself, typically operating in a competitive environment.

In fact, apart from the possibility (generally limited to procedural innovations: see Chapter 2) of exploiting technological results in secret ${ }^{15}$ or of applying for public subsidies ${ }^{16}$ (which are more and more insufficient to cover actual costs and are also often subject to limitations and restrictions such as territorial or occupational limits, as well as to often ambiguous trade-offs with the public administrations), in a capitalistic market legal system, firms cannot reliably recover their costs and receive remuneration for their investments except through patents. Only patents, indeed, guarantee the chance of a differential profit by means of the exclusive right - transferable to third parties (firms, typically), either in terms of ownership or exercise ${ }^{17}$ - to exploit the results obtained. It is obvious that in an environment of direct competition between manufacturers of identical goods, such remuneration would be highly uncertain or even impossible if (in the absence of an exclusive right) competitors were free to reproduce the new inventions/creations even immediately after the firm had launched it on the market. Having 'saved' on research costs, the competitors would enjoy a position enabling them to engage in a destructive, unsustainable price war.

15 On the protection of secrets, traditionally and generally limited to the rules against unfair competition - but recently and improvidently reconfigured in pure IPR terms in Italy, see below Chapter 2, section 9.

16 In this regard, the US Bayh-Dole Act 1980 grants federal agencies that have commissioned research with public money the right to 'march in', that is, require the contractor who may be the holder of patents to grant a licence to third parties. See, among others, M.A. LEMLEy, Are Universities Patent Trolls?, in Fordham Intell. Prop., Media \& Enter. L J., 18, 2008, p. 611.

17 The exercise of the exclusive right held solely on the basis of licences to third parties was referred to in the US Supreme Court decision in eBay Inc. et al. $v$. Mercexchange LLC of 15 May 2006 (547 US, 2006). 
As regards copyright, a large part of the world's cultural heritage had developed before copyright had even come into existence or had even been thought of (oratio publicata libera est wrote Symmahus in the fourth century AD), thanks to the force of creative impulse, fostered by sovereigns and other patrons of the arts. True, of course. But apart from the privileged - and frequently censored - character of that 'mode of production' of culture, which often corresponded to an equally privileged scope of enjoyment, only the granting of an exclusive right of protection against free riding enabled the development of publishers dedicated to multiplying and disseminating the fruits of the authors' labours. Is it a coincidence that this occurred with the advent of printing as an industrial activity?! ${ }^{18}$

Similarly, only the firm's exclusive right to its distinctive signs allows it to protect its corporate identity/image and exploit the associated goodwill in the competitive business environment that stems from freedom of enterprise, and hence allows it to (continue to) effectively receive - for the entire period that the firm operates on the market - the revenues flowing from consumers' preferential choice for its goods and services.

\section{The Dialectic with Social Interests Involved in the Overall Constitutional Framework}

It is equally true that the entrepreneurial exploitation of IPRs normally (and often deeply) 'touches' into other pockets (and brains), that is, impacts on the interests of social actors/stakeholders other than the firm. First and foremost are the communities of competitors, consumers, researchers, providers and users of information (see here arts. 19 and 27.1, Universal Declaration of Human Rights adopted by the UN General Assembly on December 10, 1948). And to the extent that such other stakeholders' interests also enjoy constitutional rank, the legal system is addressed with the need to 'harmonise'/ balance these interests with those of individual IPRs holders.

I am referring to such collective interests as for example:

- to the protection of intellectual work, the expression of human personal - creativity in all its manifestations and (hence also) in every lawful field: the object of a 'human right' enshrined in article 27(2) of the UN Universal Declaration; ${ }^{19}$

18 It is no coincidence that protection against unauthorised copying of literary works was originally afforded to printers commencing with the Renaissance library privileges. Only at a later stage (although in Venice since 1486) was it extended through the Statute of Anne in 1710 to authors, that is, content providers, one might say, for the publishing business (below Chapter 3 and associated bibliographical notes).

19 'Everyone has the right to the protection of the moral and material interests 
- to the preservation of an economic environment of freedom of enterprise and competition as the instrument of and vehicle for the efficient production and distribution of 'intellectual output' ${ }^{20}$

- finally, and above all from a systemic standpoint, ${ }^{21}$ to the development and spreading of culture, technical and scientific research, and the freedom of arts, sciences, information. ${ }^{22}$

As is well known, the modern history of IP law is deeply marked, at national as well as at international level, by the answers given to the abovementioned need for 'harmonisation'/balancing of those different interests and corresponding values. 'Different', I wish to clarify, not as to the intrinsic 'matter', but rather as to the reference to individual versus collective stakeholders. Indeed, the protection of patentees and copyright holders obviously does act directly as a stimulus to research and creative effort, and the diffusion of the fruits thereof, hence of culture and information, as much as the protection of trademark holders in principle enhances the market's competitive and transparent functioning. The true difference and the true dialectic between the interests at stake focus on the individual versus the social perspective of their pursuit. Thus, the interests of competitors and the interests of competition differ vis-à-vis not the object, but the perspective in which the 'object' is cultivated: so that the individual expression of competitive thrust can often lead to

resulting from any scientific, literary or artistic production of which he is the author' (article 27(2) of the Universal Declaration of Human Rights cit.). See also the Charter of Fundamental Rights of the European Union (Nice, 2000), article 17(2) of which includes intellectual property as one of the fundamental freedoms (see F. MASCHIO, Proprietà intelletuale e fattispecie di conflitto, Rome, 2006, pp. 9 et seq.). On the quite different profile of IPRs' possible encroachment on citizens' (different) human rights, such as access to knowledge and information, see Chapter 3, note 109, and Bibliographical Notes.

20 As explained in more detail in Chapter 3, a further and specific foundation of copyright is the principle of liberty of expression in the broadest sense. It warrants recognition and maintenance of the exclusive rights, even if the work is declared unlawful (the opposite happens in the field of patents, where the unlawfulness of the invention precludes validity).

21 Individual IPRs are to be considered a 'means to an end', as the US Supreme Court has always reiterated in its interpretation of article I, section 8 , clause 8 , of the US Constitution. See, in particular, Feist Publications Inc. v. Rural Telephone Service Co. Inc., 499 US 340 (1991) where at paragraphs 349-50, the Court states: 'The primary objective of copyright is ... to promote progress of science and useful arts. To this end copyright assures authors the right to their original expression, but encourages others to build freely upon the ideas and information conveyed by a work. This result ... is the means by which copyright advances the progress of science and art'. See also Twentieth Century Music Corp. v. Aiken, 45 Fd 2d 84, at 90-91, 422 US 151 (1975).

22 The constitutional provisions on competition must obviously be read in light of the provisions of the European Treaties (TEU and TFUE). 
a monopolistic outcome, hence to a conflict with the social interest to preserve a competitive market framework.

In analogous terms, the principle of freedom of competition, as a corollary of the more general principle of freedom of enterprise, must be interpreted and applied within a perspective of harmonisation with the principles, for example, of freedom of research and public information. Such harmonisation implies possible limitations of entrepreneurial individual freedom should the exercise thereof lead to significant injury to said other interests of equal (or even higher) constitutional rank.

As we shall see shortly below (section 9), the modern history of IP law is basically marked by the current tendency of legislators to give succour to vested interests, aimed at hardening the exclusionary powers related to the individual enjoyment of IPRs, thus privileging, often in a strongly unbalanced manner, the private interests of IPRs holders vis-à-vis the collective interests mentioned above. Of course, one cannot deny that some pro-competitive antibodies have been built into the original IPR paradigms and in the features they later evolved; moreover, other balancing factors have been provided externally, that is, (chiefly) through the application of antitrust law to the exercise of IPRs. And indeed, this interference - or intersection, as it is more commonly called - is one of the most powerful factors in the evolution that contemporary IP law is experiencing on the long way to the goal of a satisfactory (re)balancing of individual and social interests.

I will deal extensively with these developments in Chapter 5, analysing the major specific expressions of the IP/antitrust intersection. However it is appropriate at this stage to offer a few introductory remarks, specifically focused on the systemic relation between IP and antitrust law. (It's almost superfluous to recall that after the Treaty of Lisbon, in force since December 2009, the norms on competition of the EC Treaty, $81 \mathrm{ff}$., have been incorporated in the Treaty on the Functioning of the European Union, TFEU, $101 \mathrm{ff}$. Numeration apart, text and substance of the EC Treaty's rules are maintained - just as regards, in general, the acquis communautaire: art. 2, EU Treaty.)

\section{Intellectual Property and Antitrust: Distinct Rules ...}

Antitrust law is made up of a set of rules typically targeted at enterprises (private and public, operating either iure privatorum or on the basis of special or exclusive rights), and aimed at ensuring, first, that the existence of markets featuring an effective ${ }^{23}$ pluralism in terms of supply and therefore providing

23 'Effective' in the sense of 'workable', with reference to a situation of pluralism that can vice versa be 'sterilised' by intensely restrictive agreements among competitors (see Chapter 5). 
consumers with real and actual (not merely potential) alternative choices ${ }^{24}$ is not substantially threatened either by agreements in restraint of competition or by 'excessive' concentrations. Moreover, in market situations where pluralism is highly limited or even absent as a result of the concentration of 'market power' in one or a few dominant enterprises or a legal monopolist, antitrust law aims at ensuring that the behaviour of the dominant enterprise(s) does not subject the other players (smaller competitors as well as consumers, subcontractors and customers of the dominant company, etc. $)^{25}$ to significantly worse market conditions (in terms of weaker bargaining power or the 'foreclosing' of opportunities for competition) than they would have 'naturally' enjoyed in the presence of a higher degree of effective structural competition (the principle of 'as if' $(a l s o b)){ }^{26}$

For the purposes of our topic, the distinction between IP law and antitrust law revolves around two fundamental aspects.

The first concerns the subject matter of protection. The interests directly and primarily protected by IP law relate, as has been said, to the fostering of activities aimed at technological and cultural innovation, as well as the enhancement of entrepreneurial identity. Antitrust law, on the other hand, directly and primarily protects competition. This is essentially a tale of two regulations whose goals and basic regulatory principles can't be held to coincide. For example, it is true that patent law promotes (through the (cross) licence mechanism foreseen by article 31(1) TRIPs and several countries' national legislation) the freedom to compete of innovators that improve on previous inventions still under patent protection. But this happens only within the limits set by the IP norm, that is, of the set-up of a 'high profile' (technically and economically) derivative innovation. These limits are, thus, more

24 The reference to supply and demand must obviously be reversed in the case of a monopsony ('one-buyer's market').

25 Antitrust law does not outlaw a dominant position in itself, even of monopolistic proportions, where it has been achieved through 'spontaneous growth' and hence not through mergers and acquisitions or, more generally, intrinsically anticompetitive behaviours. However, some European legislations, such as the Italian, forbid dominant positions in specific 'sensitive' sectors such as radio and television (for the (hypostasised) positive effects on pluralism of information, see Law No. 249/1997) and the supply of energy (Decrees No. 79/1999 and No. 164/2000).

26 The normative expressions of the principle of freedom of competition can be partially derogated by legislative provisions (even of competition law itself, see, for example, article 81(3) of the Treaty (now 101.3 TFEU) on agreements, the merger regulation (No. 139/2004), rules on state aids, etc.) applied by judiciary and or ad hoc administrative authorities. For an incisive review of the basic principles of competition law, including from a comparative (EU/US) standpoint, an excellent starting point is G. Amato, Antitrust and the Bounds of Power: The Dilemma of Liberal Democracy in the History of the Market, Oxford, 1997. See Chapter 5 for more detail. 
restrictive than a general preference for competition would suggest, that is, they offer carte blanche for all derivative innovation developed by competitors of the holder of the original patent. By contrast, antitrust law gives the thumbs down to agreements between undertakings which, though generating a high degree of innovative efficiency, might excessively restrict competition in the relevant market (see below, Chapters 2 and 5).

The second differential aspect concerns the fact that, unlike IP law, antitrust law is designed to protect not single firms as such but the market and in particular the 'relevant market(s)', a legal concept that refers to geographic areas, classes of goods and distribution stages in respect of which the legal system checks and qualifies the impact of firms' conduct and consumers' choices. More precisely, with respect to said market(s), antitrust law as a whole aims to preserve and/or restore a 'working' (effective though imperfect) competitive market framework: a condition considered of general interest in specie of freedom of enterprise and market access for (at least potentially) all firms and freedom of choice for all consumers. Thus, the economic constitution of market-oriented systems (such as US, Europe, Japan) ${ }^{27}$ subordinates the individual freedom of competition to the general interest in a competitive market system. More precisely, unlike IP law, ${ }^{28}$ directly defending the non-material assets of single firms - and indirectly, so to speak by reflection, the general interest in the progress of innovation and culture - antitrust law essentially places an external limit upon the firm's conduct, aimed at directly protecting the general interest in a competitive market - and only subordinately that of individual firms threatened or damaged by anti-competitive manoeuvres. In this sense, the motto of antitrust could be 'first competition, then the competitors'.

\section{7. ... But Nonetheless Dialectally Intertwined}

This systemic distinction, which indicates the limits to an across-the-board reciprocal convergence of the two regulatory frameworks, should not however overshadow a more complex intertwining of relationships and functions between the two.

The protection of IPRs is not in itself contradictory with the enhancement of free market competition. In fact, the very attribution of limited exclusive

27 On the latter see the analysis by E. KAMEOKA, Efficiency claims in Japanese merger control: a comparative overview, in Concorrenza e mercato, 2005-2006, p. 251.

28 Moreover, as we shall see (Chapter 5), the most modern interpretative approaches, as well as several EC Directives, express a broader, non-corporatist vision of market protection. 
rights over new creations, as well as trademark rights, serves competitive dynamics.

Patents do serve as an incentive to competition based on innovation. Trademarks assure a distinction among the various (sources of) offers on the market and hence they enhance, together with the individual identity and goodwill of single firms, the 'transparency' and hence the efficiency of a competitive market. On the other hand, the exclusivity inherent in patents, aimed at granting a differential advantage (primarily in terms of price: Chapter 2 ), and that are inherent in distinctive signs, aimed at avoiding the confusion/poaching of customers, would have no meaningful role in a perfectly monopolistic market.

Moreover, the exclusivity of an IPR, which satisfies a monopolistic-type interest, is granted as a means of furthering the collective goal, of constitutional rank (as first stated in the US: see article 1, section 8, clause 8, of the American Constitution), of fostering activities aimed at producing and diffusing inventions and creative works. Also these activities of business enterprises are to be placed within a constitutional framework informed by the general principle of freedom of competition.

The existence of this multifaceted functional nexus is confirmed by the very origins of modern IP law (as founded on equal rights rather than privileges). I will briefly recall two salient examples. The limit fixed by the Statute of Anne 1710 on the term of the exclusive right granted to printers and authors was twice the term of employees' non-compete obligations under the rules of ancient corporations. In substance, it was aimed at granting competitors and followers access to a regime of free competition.

The second example is the famous reference to intellectual property as 'the most sacred' ('la plus sacrée'), made by Le Chapelier in introducing the first post-revolutionary law (1791) granting the droit d'auteur. That expression on which IP hardliners have often speculated - was in truth drawn (without citing it!) from the Turgot Edict of 1786, from the part devoted to the 'ownership of one's own work' (propriété du travail), as precisely the acknowledged right of each citizen-worker to get rid of the restrictions on freedom of trade imposed by maitrises et jurandes. ${ }^{29}$

29 See respectively Rapport de M. Le Chapelier on the Law of 13 January 1791, and A.R.J. TuRGOT, Édit du roi portant suppression des jurandes et communautés de commerce, arts et métiers, 1776. That emphatic wording, often invoked by advocates of protectionist features of IP law, originates on the contrary in a context of the exaltation of freedom of competition. Indeed, Le Chapelier envisaged exclusivity solely for works that had not yet been published and even then as an exceptional situation compared to the public domain (J.C. Ginsburg, A Tale of Two Copyrights: Literary Property in Revolutionary France and America, in R.P. MERGES and J.C. Ginsburg (eds), Foundations of Intellectual Property, New York, 2004, pp. 288 et seq. 
More specifically, IP law aims at striking a balance (with perhaps greater equilibrium in patent law: Chapter 2) between the individual interests of the rightholders and those of present or future competing innovators and distributors of patented products. This balance has long-range, 'diffuse' effects (including potential effects) on the so-called 'innovation' market, which contribute to the competitive character of that market - and this from the standpoint of both horizontal ('inter-brand') competition among different technologies and vertical ('intra-brand') competition among distributors of the same patented product.

Some examples of the basic precepts of patent law which 'balance' the patentee's exclusive/exclusionary rights so as to promote competition, are: (a) the provision of a certain, fixed time limit on the exclusive right, which ensures and defines with certainty the future prospects of direct competition with the patent holder; (b) the so-called 'exhaustion' of patent right, which moderates price levels along the distribution chain; (c) the disclosure of the invention and the publication of its application, which together provide the public - that is, competitors - with adequate information about the new invention, thereby facilitating subsequent competitive innovation - either substitutive or derivative; (d) the restriction of the scope of the patent to a specific technical solution instead of a type of utility, ${ }^{30}$ thereby allowing for the immediate development of competing alternatives (see further Chapter 2).

On the other hand, antitrust law does not in itself hinder the granting and enjoyment of IPRs, but simply conditions the manner of their exercise so that the monopolistic effect that such exercise implies ${ }^{31}$ does not exceed the level necessary to satisfy their essential function of granting a chance of differential remuneration in order to foster innovation and creativity, or protection of trade identity. Here we can see an analogy with the principle of antitrust law (article 86(2) of the EC Treaty, now art. 102 TFEU) governing monopolies for public interest services, that is, the principle whereby the recognition of monopoly rights is limited to the scope necessary for meeting the public service obligations for which such rights were granted.

In short, it can be confirmed that the intellectual property paradigms often contain built-in 'antibodies' that reduce the impact of exclusive rights on the interplay of competition. By the same token, antitrust law's mission is also to contain the exercise of IPRs within limits compatible with the general interest of safeguarding a 'workable' competitive fabric of the market(s) concerned.

30 ' $[. .$.$] the common function of two industrial patents does not imply per se that$ one infringes the other but just that the solution adopted is the same': Supreme Court (Civil Division) judgment no. 17993, in Foro It., 2006, I, 114.

31 Below Chapter 5, section 5. 
As further confirmation of the absence of any irremediable enmity between the two branches of law, it should be remembered that antitrust law does not hinder (provided the restrictive effects are not 'excessive') contractual limitations upon the exercise of IPRs that are reasonably necessary to achieve efficient innovation. Some years ago Professor Robert Pitofsky, former Chairman of the Federal Trade Commission, pointed out that on only one occasion throughout the entire history of antitrust law in the US a research and development joint venture was called to account for breaching antitrust provisions. And the European Community has increasingly shown special leniency accentuated with Regulation (EC) No. 2659/2000 - towards agreements in the field of research and development, even though they may provide for the joint development and exploitation of 'results which are protected by intellectual property rights' (article 3(4) of the said Regulation). Further, through Regulation (EC) No. 772/2004 (below, Chapter 5) it has also adopted a more flexible approach regarding the transfer of technology protected by IPRs. Borrowing the formulae of property law, it can be said that the powers to enjoy (exclude) as well as the power to dispose (license) that a rightholder has and which intrinsically restrict competition in production and distribution can be exercised if and to the extent that they do not conflict with the maintenance of 'workable' competition in the markets concerned (that is, both the primary ('horizontal') market of goods protected by IPRs and the related upstream or downstream ones: see Chapters 2 and 5 for more).

The foregoing observations lead to a teleological reflection regarding the ties between intellectual property and antitrust. As some authoritative economists have been stressing for some time now, the latter discipline fosters innovation, although from the opposite angle to intellectual property. By hindering entrepreneurs from becoming and consolidating their positions as rent-seekers, antitrust law encourages firms - all firms - to develop new products and processes, so as to acquire future competitive advantages from their inventions. That incentive importantly targets both the incumbents who are driven towards further innovation in order to maintain and expand their current market share and the challengers who focus their R\&D efforts on developing innovative solutions that could unseat the incumbents.

There is a final but no less important aspect of the intersection between IP and antitrust law that is worthy of note. In specific circumstances (see Chapter 5), IPRs can contribute to creating or reinforcing 'market power' in an antitrust sense. Thus, the ownership and/or exercise thereof can be used to reinforce the 'dominant position' of one or more undertakings for the purposes of investigating abuses and reviewing concentrations. For example, competition authorities, and courts, have in certain cases equated copyrighted software with an essential facility, hence affirming the obligation to grant competitors access to the relevant source codes (see below, Chapter 5, in connection with the 
European Microsoft cases). Or, think of the role that concentration in the same hands of control of important patents and trademarks could play in a merger being deemed 'incompatible' with antitrust rules.

In conclusion, albeit pursuing the protection of distinct goals, each branch of the law often ends up indirectly promoting, from many standpoints, the same kind of interests specifically and directly protected by the other in the development of innovation and the protection of competition). Now, it is just this frequent, multifaceted 'parallel convergence' that justifies IP law being interpreted in the light of the same overarching principle, of constitutional rank, that guides antitrust law, that is, freedom of enterprise and competition as 'harmonised' with the other constitutional principles protecting and enhancing the different social interests also involved in the dynamics of IPRs' exercise.

\section{The Guiding Principles}

Consistency with that overarching principle gives rise to two main guidelines in construing and applying IP (and unfair competition) law.

The first is the principle of numerus clausus, according to which IPRs are strictly defined by law in number and kind. ${ }^{32}$ This is because IPRs grant powers in restraint of competition, and are therefore to be deemed exceptions to the constitutional principle of economic freedom. Needless to say, acknowledging this principle does not hinder the extension by legislation - solely by legislation and not interpretation - of the nucleus of IPRs beyond those currently protected. Historically, in fact, these rights have been progressively extended: one need only to consider, for example, the 'new' exclusive rights introduced on the layout design for integrated circuits.

The correct application of this principle requires another guideline to be followed in interpretation: care must be taken to ensure that no functions of intellectual property protection are surreptitiously attributed to other branches of law which, while pursuing other functions, could refer to IPRs-protectable subject matter. In particular, special attention must be paid to avoiding (mis)interpretations, frequent in certain countries, of the rules against unfair competition. I refer to interpretations that unduly invest such rules with a crypto-patent function exceeding their own proper sphere of application. Think, for example, of the tendency to extend the prohibition against passing-off

32 Obviously the numerus clausus pertains to the 'list' of IPRs as such and certainly not to their material 'subject-matter', which has sometimes been left undetermined: one need only consider, in particular, the varied family of so-called 'atypical distinctive markings', protected under the unitary regulatory reference to the distinguishing function (see Chapter 4). 
beyond the limits sufficient to contain the risk of confusion (see Chapter 4), thereby infringing the valuable principle: "no misappropriation without misrepresentation'.

The second interpretative guideline to be followed is to constantly favour a pro-competition construction of IP law, even when the wording might in itself allow a different interpretation. More specifically, while always respecting the IPRs' inherent function (protecting innovators against free riding, or firms' and products' identity and renown against misrepresentation), the rule(s) must be construed, to the extent that the wording allows, in a manner that defends and promotes rather than erodes the economic freedom of third parties, as well as the market's competitive fabric. It is in compliance with this guideline, for instance, that patent law has been construed in Europe so as to avoid extending a patent's scope to all the possible uses of an invention, but to limit it to the particular technical field and technical solution that the inventor has specifically claimed in the patent application (see Rule 42 and 43, 'Content of the description' and 'Form and content of claims' of the 'Implementing Regulations' of the European Patent Convention ${ }^{33}$ and article 5(3) of the European 'Biotech' Directive 98/44 EC ${ }^{34}$ ).

Following these guidelines not only ensures that IPR law remains consistent with the guiding principle of free competition, but also with the constitutional goal of promoting research and culture. For instance, if the rules on infringement were to be construed so as to extend the scope of exclusive rights beyond the strict quid inventum, the development of subsequent innovation would be discouraged. Third parties (competitors of the patent holder) penalised by such an interpretation would in fact have no incentive to invest in 'too' risky attempts at improving and/or modifying previously patented techniques. And the patent holder herself, benefiting from such an overprotectionist interpretation, would be tempted to make 'rent' out of her acquired competitive advantage, rather than being stimulated to further invest in research and innovation.

33 'The description shall: ... c) set out the invention ... in terms that the technical problem can be understood, ... and its solution; f) specify in detail at least one way of implementing the invention ...; g) expressly indicate ... how the latter is apt to be an industrial application'. For more on the content and requisites of the description, see Chapter 2.

34 Said article demands that the industrial application of a sequence or a partial sequence of a gene be disclosed in the patent application. See more in Chapter 2, section 4 . 


\section{Current Protectionist Trends}

Risks of this sort become all the more evident in light of 'overprotectionist' interpretative tendencies ${ }^{35}$ that have periodically emerged throughout the history of IP law and that glaringly emerge today as a result of several major developments in the technological and economic domain. I am referring in particular to legislative initiatives and hermeneutic trends often vigorously promoted worldwide from across the Atlantic - a sort of Washington Consensus on intellectual property. ${ }^{36}$

These trends generally, and in relation to specific principles and industries, are substantially shifting the centre of intellectual property law further towards 'monopoly' rather than towards 'competition', so much so as to lead to what has been described by Jerome Reichman as 'a discredited intellectual property system [that] risks collapsing of its own overprotectionist weight' ${ }^{37}$ The risk of collapse (the risk of 'corporative regression' that departs from the liberalist and pro-competitive spirit of the classical model) arises precisely from the danger that intellectual property rights could be transformed from a tool for the promotion of innovation and competition, into a protectionist barrier in favour of dominant enterprises: that is to say, into a factor that restricts supply and slows down the dynamic processes that generate innovation, while also reducing consumers' alternatives of choice.

This danger, it must be noted, is much more acute vis-à-vis the contemporary tendency of markets to take on an oligopolistic structure. This tendency threatens all market 'players': small competitors, both current and potential,

35 In a civil law tradition like the Italian one, corporatist pressures are felt mainly at interpretative level but the ensuing practices can then end up being codified. Let me quote, especially for the younger generations, the famous remark of an eminent Italian scholar of the late 19th and early 20th centuries, Cesare Vivante, a cultural disciple of Levin Goldschmidt, on the formation of the Commercial Code (C. VIVANTE, Trattato di diritto commerciale, I, Milan, 1922, Introduction, p. 12): 'To compile the new Code our legislator called upon industrialists, bankers, insurers, railway companies and chambers of commerce (they too protectors of the interests of trade), in other words men who in their careers and teachings were used to defending business interests, and then said to consumers: here is the Code that applies to you too. Therefore, a classbiased law came about ...'.

36 I again refer to the quoted essay by M.P. RYAN, Knowledge Diplomacy: Global Competition and the Politics of Intellectual Property, Washington, DC 1998. Beginning 2009, though, we can (also) reasonably hope for a 'change' of that consensus's direction towards more balanced, and equitable, IP regimes. On this, more in the Appendix.

37 J.H. ReICHMAn, Beyond the Historical Lines of Demarcation: Competition Law, Intellectual Property Rights and International Trade after the GATT's Uruguay Round, 20 Brook. J. of Int'l Law, 1993, 119. 
who are increasingly deprived of opportunities for competition; consumers, whose range of choice is increasingly limited by sparse offerings marketed at exorbitant prices. And even in the long term, the dominant firms themselves, encouraged to go on reaping the fruit of their guaranteed earnings, might well be tempted to slow down the pace of further investments in innovation.

\section{Specific Examples}

In modern times, the overprotectionist trends (in both making and interpreting rules), whose risks we have just mentioned, have manifested themselves along three main lines.

I. First, the extension (under various teleologically convergent aspects) of the scope of the protection afforded by exclusive rights. Just to recall a few examples, the protection of trademarks has been expanded beyond the limits of its fundamental function of distinguishing firms and products from others, to cover business sectors that are quite different and sometimes even remote from those in which the trademark holder operates. Patent protection, too, has also been expanded in some jurisdictions, even by court law, to cover fields of use that were not contemplated or claimed by the patent holder. Recurring attempts drive towards the upgrading of industrial secrets to IPRs (see the Italian experience, Chapter 2, section 9).

As far as copyright is concerned, take for example the creation of new forms of digital infringement related to the protection of 'anti-access' software (so-called 'technological protection measures', TPM), ${ }^{38}$ thereby putting at risk, at least in practice, the freedom of access to and use of works, data and information that are not, or cannot be, covered by copyright in the first place. A further example is the extension of the copyright term, which has been progressively lengthened to the current (but probably not yet definitive) term of 70 years from the death of the author (see Directive 2006/116/EC ${ }^{39}$ ), amending previous Directive 93/98/EC. ${ }^{40}$

Patents have fortunately not had their term extended (the introduction of complementary protection certificates for pharmaceutical and phytosanitary patents is not, if properly applied, a form of extension: see below, Chapter 2). But results that achieve similar effects are frequently produced by deliberate

38 See Chapter 3, section 6 for a critique of Directive 2001/29 EC on the Information Society (the so-called InfoSoc Directive).

39 Directive 2006/116/EC of the European Parliament and of the Council of 12 December 2006 on the term of protection of copyright and certain related rights (codified version), OJ L 372, 27.12.2006, pp. 12-18.

40 Council Directive 93/98/EEC of 29 October 1993 harmonising the term of protection of copyright and certain related rights, OJ L 290, 24.11.1993, pp. 9-13. 
laxity on the part of patent offices and the courts: the former often granting and the latter upholding 'derivative' patents (filed by the original inventor) of dubious inventive character, at times merely the result of astute rewording of previous patents, thus surreptitiously made 'evergreen'. ${ }^{41}$

II. Second, the replacement, in a wide variety of new technological sectors, especially information technology sectors (ITs), of patent protection, rich in pro-competitive antibodies (see Chapter 2), by the copyright regime, which features a more intense pro-monopolistic bent (see Chapter 3 ).

III. Third, but not least, the attempt to include within the scope of IPRs protection types of intellectual creation which, whilst linked to innovationgenerating processes, have traditionally been considered to fall into the public domain and therefore be open to free competition. Some examples are the proposals aimed at eroding the principle of the non-patentability of the results of basic scientific research and mere business and game plans and methods, as well as calling for a thoroughly 'reductionist' revision of the list of nonpatentable subject matter included in article 52 of the European Patent Convention. Again, the ambiguous prospect of having the expression of diverse local cultures (so-called 'traditional knowledge' and folklore) be the subject matter of IPRs: a prospect which if not governed by wise specific regulation could lead to the total privatisation - hence across-the-board appropriation - of elements that should more correctly be considered as cultural domain. $^{42}$

41 On the Glivec case (Novartis v. Union of India and Others, Madras High Court, 2007: http://www.lawyerscollective.org/\%5Eamtc/current_issues/Judgement. pdf), see S. BASHEER and T. Prashant Readdy, The 'Efficacy' of Indian Patent Law: Ironing out the Creases in Section 3(d), Script-ed, Vol. 5, Issue 2, August 2008, available at: http://ssrn.com/abstract=1086254.

42 In rectifying in this sense a previously expressed opinion (G. GHIDINI and E. Arezzo, From Huts to Labs and Back Again: Stimulating the Production of Biodiversity-based Drugs while Ensuring an Equitable Sharing of the Benefits Flowing Thereby, in H. Ullrich and I. Govaere (eds), Intellectual Property, Public Policy, and International Trade, Brussels, 2007, p. 77), I totally agree with the proposal to introduce a sort of misappropriation ban (fully compatible with the domain principle) to protect indigenous communities against the misappropriation of their biodiversity and associated traditional knowledge. On this topic, see in particular WIPO's documents, such as proposals, the most recent version of which is The Protection of Traditional Knowledge: Draft Objectives and Principles, WIPO/GRTFK/IC/10/5, submitted at the tenth meeting of the WIPO Intergovernmental Committee on Intellectual Property and Genetic Resources, Traditional Knowledge and Folklore, held in Geneva from 30 November to 8 December 2006, available at http://www.wipo.int/edocs/mdocs/tk/en/wipo_ grtkf_ic_10/wipo_grtkf_ic_10_5.doc. See also the 2009 WIPO Draft report of the Intergovernmental Committee on Intellectual Property Resources, Traditional Knowledge and Folklore, WIPO/GRTKF/IC/14/12 Prov.2, available at: http://www. wipo.int/edocs/mdocs/tk/en/wipo_grtkf_ic_14/wipo_grtkf_ic_14_12_prov_2.doc. 
What is the driving force behind such trends? First and foremost, I believe, it is the industrialised world's quest for new sources of competitive advantage on global markets as it gradually loses its pre-eminence in 'mature' sectors. Hence, the increasing attention to innovative technologies and the protection of their exclusive exploitation as a means of maximising (in the short term) the return on investments. In its turn, this rationale - dèja $v u$ in historical cycles of industrial revolutions - stems from some typical aspects of the current industrial and financial context of technological innovation.

Amongst such (well-known) factors, we can briefly consider:

- the growing extension of competitive conflicts based on technological innovation to ever larger markets, typically on an international scale;

- the increase, exponential in some sectors, of research and development, distribution and advertising costs (more so, often, than production costs in the strict sense);

- the chronic insufficiency, as a result of the widespread implementation of cost-cutting policies, of government subsidies for scientific research, that is, the raw material for applied (industrial) research. The business community is increasingly being called upon to cover costs of scientific research that were traditionally borne by universities and public institutions, ${ }^{43}$

- the need, arising from the factors illustrated above, to attract ever greater amounts of venture capital. Typically, this need is met in financial markets featuring increasingly intense competition in offerings, making equity investments more attractive. In turn, such financial

Specifically as concerns folklore, I believe it should be denied any possibility by the pro tempore representatives of communities at all levels, whether villages or entire countries, to alienate assets that belong to the community itself in a historical-institutional sense, such assets constituting cultural heritage in the public domain. What it should be possible to grant are temporary licences to use said cultural assets in a manner and according to terms capable of preserving their integrity and defending their dignity and reputation. On this highly sensitive issue, see amongst others N. MEZGHANI, La protection $d u$ folklore, des créations populaires ed du savoir traditionnel, in G. GHIDINI and L.M. GENOVESI (eds), Intellectual Property and Market Power - ATRIP Papers 2006-2007, Buenos Aires, 2008, p. 313; J. GIBSON, Knowledge and Other Values: Intellectual Property and the Limitations for Traditional Knowledge, in G. WestKamp (ed.), Emerging Issues in Modern Intellectual Property: Trade, Technology, Market Freedom, Essays in Memory of Herchel Smith, Cheltenham, UK, 2007, p. 309.

43 In countries where the system encourages the practice (in the US, since 1980, thanks to the Bayh-Dole Act), universities themselves increasingly tend, for obvious economic reasons, to engage in applied research with a view to patenting the results and later licensing the resulting patents for industrial exploitations. Briefly put, they tend to bring their research policies in line with the R\&D goals typical of corporations. In so doing, they risk losing sight of their mission to lead basic research. 
competition drives corporate policies aimed at maximising shareholder value in the short term. Thus, such policies often reflect a financial logic, at times exaggerated, rather than an industrial one aimed at the constant, long-term development of the industrial activity. Now, those short-term financial needs lead to a preference for 'stronger' forms of protection of IPRs as 'value-generating' instruments, whether on a commercial level (licences, merchandising etc.) or a directly financial one (think, for example, of IPR securitisation). This even applies at the accounting level: I refer to the possibility of registering IPRs in the balance sheet at a 'fair value' (higher than the traditional 'historic cost'), following the new International Accounting Standards, in particular IAS 38).

- the ease of immediate and 'perfect' (indistinguishable from the original) duplication of the output of new technologies, such as computer programs (due to their 'bearing the know-how on their surface', to borrow J.H. Reichman's words) and bioengineering (due to the typical self-reproducibility of biogenetic material). Such ease annuls the natural 'lead time' of innovators and thereby jeopardises the recoupment of first-comers' investments.

\section{Signs of an About-turn ...}

History is always on the move, even in the field of intellectual property law. In the last few years and in particular in the brief period of time since the publication of Intellectual Property and Competition Law (2006), the hyperprotectionist tendencies are encountering signs of ever increasing opposition. Such signs are an important harbinger of an about-turn since they no longer come only from social activists or restricted academic circles swimming against the stream. Those circles themselves are expanding at a swift pace. This nouvelle vague of reform initiatives, organised by leading universities and research institutes, witnesses to a wider than usual academic sensitivity not only to issues linked to IP regulation's impact on the generation of innovation, and competition, but also to its broad social, and geopolitical, effects.

But the really breaking news is a definite distancing from the protectionist models described above by an increasing number of representatives from the world of industry and finance involved in research and development (primarily, but not only in the IT and communications fields). They advocate different business models that are not always premised on an across-the-board exclusionary view of IPRs. In other words, from within the business world a growing number of authoritative voices bear witness to the fact that, without prejudice to the essential prohibition on free riding, methods of production and 
distribution involving forms of open or cooperative exploitation of IPRprotected innovations are equally, and at times even more, capable of 'creating value' (as the fashionable expression goes).

This phenomenon of sharp and insightful dissociation by industrial interests from highly protectionist models of intellectual property had in truth already shown itself several times in Europe: more recently at the time of the European debate on the proposed Directive on software-related patents, and years before on the so-called sui generis right over the information stored in databases, ${ }^{44}$ and earlier on the copyright protection of computer programs. ${ }^{45}$

More precisely, in recent years that growing 'difference' (vive la différence!) has manifested itself on two distinct levels of economic relations.

The first concerns innovators and third-party operators (direct competitors as well as rivals in downstream or upstream markets). In particular, the IT industry (a typical network industry: see Chapter 5) has envisaged the need to use reciprocally compatible (interoperable) components and products as a prerequisite for greater overall productivity both for horizontal product lines as well as for vertical (upstream or downstream) lines. This has led to pressure to open up to third-party operators (paying licensees, not free riders!) access to innovations which, by reason of top-notch quality, public liking or regulatory authority decision, have become standards, and whose protection through patents or copyright would constitute a formal, further barrier to market entry by third parties.

What is involved are not isolated or ephemeral episodes. Testimony to the growing affirmation of this new entrepreneurial approach is the ever more frequent interlinking between closed and open models of exploitation of intellectual property rights, the latter based on 'sharing'. In particular, the open source licence model, initially conceived to favour a somewhat restrictive community of amateur programmers, has given life to a veritable industrial option (more than a pure alternative, as the interlinking mentioned above testifies). Thus giants like Microsoft and IBM embarked at least partially upon new paths using IT more oriented towards sharing, no longer rejecting acrossthe-board access by third parties to portions of their technology protected by IPRs. (Things have got to the point, once unimaginable, that the patent system has been criticised in that it does not prescribe the disclosure of the source code for software-related inventions.)

44 Granted by Directive 96/9 to the 'maker' of the database (collector and organiser of information) as distinguished from the author, in the proper sense, that is, the 'architect' of the database mainframe (structure). See Ch. 3, § 14.

45 F.J. Huet and J. Ginsburg, Computer Programs in Europe: A Comparative Analysis of the 1991 Software Directive, 30 Colum. J. Transnat'l L., 1992, p. 338. 
The philosophy of sharing as a premise for achieving more advanced (efficient) industrial patterns (new business models in jargon) is not limited to the information technologies business. A similar change of policy and heart can be detected also in the editorial and entertainment business in two distinct directions: the production of new 'content' (stimulus to creativity) and the relationship with the end user/customer of the same.

As regards the first aspect, one must consider the industrial necessity of keeping up with the increased transmission capacity brought about by new technologies (in particular, broadband and wireless), that is, it is necessary to fill up new available channels to avoid having 'more high-speed networks than they know what to do with'. ${ }^{46}$ It is in this context that one witnesses a resurfacing of the once 'unacceptable' possibility of giving more liberty to develop 'derivative works', that is, transformations and/or additions to previous creations, even including the rapidly expanding frontier of interactivity between the producers and consumers of those contents. It is here that the absolutely exclusionary model of copyright first appeared to many to be just red tape, or indeed a strait-jacket, compared to the new promising production and distribution models. As The Economist stated in 2003, a 'radical rethink' of copyright in a reductionist sense was called for in order 'to foster creativity in the digital age'. ${ }^{47}$

As regards the second aspect, a fact that was unthinkable until a short time ago seems worthy of comment. Some high priests from leading IT and communications companies have expressed their growing dislike of, if not actual hostility towards, the maintenance and defence of those 'technological protection measures' (TPM) capable of hindering access to and the exchange of digital data, information, text, images, music etc. in communication networks. (As we shall see in Chapter 3, this use can at times become misuse, when the contents involved are not copyrighted or even copyrightable, or however subject, albeit under certain conditions, to free access and use for purposes of research, study, cultural and civil debate, etc.) This, too, is not a case of an ideological conversion. As in the aforementioned cases, it is a different perception of business interests which drives a more 'open' approach - and makes it quite significant. In short, some discerning and far-sighted minds in the information, culture and entertainment businesses have come to understand:

46 'A World of Connections: Special Report on Telecoms', in The Economist, 28 April-4 May 2007.

47 This also confirms that the tendency to extend the open licence models conceived for computer programmers to the wider cultural industry is not just a passing phase: just think of the current growth in creative commons licences. 
- that a policy of obstacles or even legal persecution of individual users can be a wasted effort not only because of the legal costs, ${ }^{48}$ but above all because of the negative effects on the social consensus (that is, on image and hence customers) that firms need to retain, especially in sectors of 'mass' consumption, in order to grow and face the competition;

- that firms can adopt (different) business models and distribution policies - that enable access to and exchange of content at a low price (at times even free of charge) and still 'make money'. These different policies are mainly based on other sources of income such as low cost subscriptions, online advertising and offers of additional services (both 'linked' to the content transmitted), sponsorships, 'live' performances, including an 'invisible' price increase of the hardware (for example, mobile phones) used for downloading content (see also below, Ch. $3, \S$ 19).

Thus, the user pays just a little or indeed nothing at all (in return, agreeing to be the recipient - 'contact' - of advertising) and the firm earns from sources other than the straight 'price', thereby avoiding the costs (monetary and image-wise) of having to pursue users and/or servers through the courts. At this point, TPMs, the electronic copyright padlock, may ${ }^{49}$ come to be as antiquated and cumbersome as chastity belts (and just as ineffective).

This is not all. In sectors other than those strictly linked to communications, and not normally thought of in terms of network industries, such as biotechnology, 'open licence' systems are gathering ground as the most efficient models of creating innovation. These are at times 'open' without any defined limits along the lines of the open source model. More often new technologies are made-and-shared (through patent pools and/or cross-licences) within the context of collaborative production systems, that is, 'open' within a pre-

48 So much so that the majors prefer to strike at the servers, much easier to identify and certainly, unlike users, capable of paying large sums in compensation. Testimony to this practice are the Napster, Kazaa and Grokster cases (below Chapter 3). That said, I believe that this practice is declining in light of the new developments described in the text.

49 I say 'may' having in mind the possibility that in specific cases, or specific economic circumstances, those other sources of revenue end up being inadequate. In several countries, this seems at present to be the case with online editions of newspapers, owing to the fact that a dramatic drop in 'paper' advertising, linked to the current global economic crisis, is not compensated by the revenues from online advertising. Hence the choice of some publishers to request a payment, applying TPM to their once often free online editions. I trust that such policies will be reversed as soon as the crisis eventually comes to an end. 
determined group of firms that cooperate with one another in R\&D while remaining competitors on the market.

This occurs at present and has also occurred for a considerable time in more traditional industries (for example, components for cars and household goods). Here, there has been a silently growing affirmation of industrial models based on technical standards that are the fruit of cooperation while competition is played out in the field of design, brand, marketing policies etc. Important parts of the frame, engines and working mechanisms in automobiles from various car manufacturers are to an increasing extent the product of cooperation, with competition focusing on marketing. As recent international experience shows, such cooperation among competitors (co-opetition) often extends to the level of $\mathrm{R} \& \mathrm{D}$, and envisages not simply the reciprocal free sharing of results, but also the co-patenting or cross-licensing thereof, or even the reciprocal foregoing of patenting. Thus, as hinted, only the last mile of the industrial process, that is, refinement, marketing and ready-to-market industrial applications, rests solely upon each competitor's own strategy.

This 'cooperative' trend is worthy of encouragement for its higher innovative potential, notwithstanding the inherent risks (to be properly addressed by a pro-competitive regulation of $\mathrm{R} \& \mathrm{D}$ agreements and/or by antitrust law tout court) of 'collateral' covenants aimed at restraining the exploitation on the market of the innovation jointly developed - either with reference to prices or even the 'timing' of the marketing itself of the new products.

The evident reasons for this ever growing trend are twofold. First, there are cost efficiency motives that compel the achievement of cost savings, even in R\&D activities, vis-à-vis the erosion of profit margins implied by increased competition. ${ }^{50}$ Such cost efficiency tends to be attained, by the way, more through flexible cooperation agreements than through mergers (so frequently leading to disappointment compared to the expectations that inspired them). Second, international expansion puts pressure on businesses to increase the compatibility of parts and products and hence to intensify processes of standardisation.

All this, therefore, leads to a multiplication of forms of industrial cooperation in which the necessary recourse to the above-cited contractual instruments (cross-licences, patent pools, etc.) encourages forms of intellectual property exploitation that - without facilitating free riding - drive towards a broader sharing of innovation as well as a wider dynamic participation in the creation thereof. I must just add that this trend is swiftly growing beyond the circle of the established industrial world, increasingly encompassing the developmental

50 The more so, may I add, in times of deep economic crisis such as the world is currently experiencing: a situation that typically highlights the cost-related benefits of business cooperation, even at R\&D level. 
dynamics of, and industrial relations with, many developing countries. In turn, as we shall see in the Appendix, this geopolitical profile is assuming increasing relevance as concerns the future re-shaping of the IP international regime - hopefully heading towards more fair - and far-sighted - equilibria.

In conclusion, we are witnessing the emergence of different models of creation and enjoyment of intangible goods, which work to modify the traditional 'omni-excludent' intellectual property paradigms. These models do not impair the essential function of IPRs, that is, prevent and enforce free riding (free riders don't pay, licensees always do! ${ }^{51}$ ), while often proving more efficiency for the advancement of research and development and industry across the board.

\section{Keep a Tight Hold on the Helm}

Is there a new wind blowing, then, through the world of intellectual property? Or is it just a breeze that moves the curtains in the palace of the Leopard, a metaphor of just an apparent change. Personally, I am cautiously optimistic, in view of all the economic, cultural and geopolitical factors cited above, and the correspondingly evolving attitudes, even in the business world, that are pressing for more 'open' intellectual property models. These models objectively reflect an attempt to reconcile the incentives to private efforts and investments in innovation and individual competitiveness with the satisfactory preservation of a 'workable' competitive market, enhancement of culture, science and research, freedom of information, etc.

Certainly, one must be realistic about the overall state of progress of these new trends. National and European lawmakers and judges have so far given ambiguous signals. Let us consider a few examples (see further below, Chapters 2 and 3). On the one hand, the European Parliament (and the Commission) have refused to allow mere business methods to be patented ${ }^{52}$; and the Biotechnology Directive (98/44/EC) has excluded the patentability of genes and gene sequences per se (more in Chapter 2, section 4). On the other hand, the Directive on Copyright in the 'Information Society' (InfoSoc,

\section{Below Chapter 5.}

52 Let us not forget, however, that the European Patent Office has for more than thirty years now (starting with Vicom/Computer-Related Invention, T208/84, 1987 EPOR 74) been granting patents on inventions implemented through computers, even when the patents concern a business method, provided it is computer implemented (see Sohei/General Purpose Management System, T769/92, 1996 EPOR 253) and the invention is shown to produce a so-called technical contribution (see G. GHIDINI, E. Arezzo, C. De RASIS and P. ERrico, Il software fra brevetto e diritto d'autore: Primi appunti sulla Proposta di Direttiva comunitaria sulle invenzioni attuate per mezzo di elaboratori elettronici, in Riv dir. Ind., 2005, I, pp. 46 et seq.). 
29/2001 EC) has significantly strengthened the exclusionary powers of copyright-and-neighbouring rights-holders vis-à-vis third parties' faculties of access and use of data and information (even if) relevant for purposes of research and education (see Chapter 3, section 6). Moreover, the European Parliament has adopted a resolution on first reading ${ }^{53}$ that makes it a criminal offence to engage in the somewhat vague act of 'facilitating' infringement, thus risking the punishment of mere 'supply of access' to networks. And let us not forget the protectionist slip of the Italian Industrial Property Code (IPC, 2005) relating to the protection of industrial and business secrets (below Chapter 2, section 9).

Thus, cautious optimism is called for. While acknowledging several significant dynamic developments in the conceptual approach to IP law interpretation and application, one must nonetheless be vigilant in opposing the hyper-protectionist trends that are still widespread and often have hegemony, driven by corporate interests that often hold legislators hostage - even quite visibly, at times, as in the case, for example, of the EC Directive on the Information Society (below, Chapter 3). To do this, one must follow the simple but not always easy recipe of privileging, in the interpretation and application of IP law, the guiding role of the constitutional principle of freedom of competition in harmony with the other principles protecting those social interests of constitutional rank at stake. And indeed consistency with those principles that 'bundle' of constitutional principles - appears ever more necessary as new technological and economic challenges, as well as renewed corporatist pressures, call for a rethink of traditional interpretative categories and even tend to modify the regulatory framework by pushing towards fragmentation on the one hand and hybridisation on the other of the fundamental paradigms patents, copyright, trademarks.

Accordingly, the analysis of the basic principles of intellectual property law in this book will primarily attempt to analyse the effective capacity of the IP system to evolve in step with the contemporary economic and technological context, so as to ensure a satisfactory balance for the various interests and values involved. These interests and values refer to a dynamic, pro-competitive enhancement of innovation, dissemination, and freedom, of science, culture and information, as well as the freedom of choice of consumers.

In the course of this analysis of the basic paradigms of IP law in accordance with the constitutional framework, I will avoid any forced 'harmonisation' of

53 Resolution of the European Parliament of 25 April 2007 on the amended proposal for a Directive of the European Parliament and of the Council on criminal measures aimed at ensuring the enforcement of intellectual property rights (COM (2006) 0168 - C6-0233/2005 - 2005/0127(COD)). 
the various specific paradigms of IP law, each with its own peculiar combination/balance of 'monopoly' and 'freedom'. IPRs cannot be dealt with en bloc. More precisely, the persistence of often quite large differences between the various positive paradigms and/or leading interpretative trends coexists with the fact that the contemporary 'global' intellectual property debate reflects legal (and economic) principles and lines of development argument that show a high degree of 'language', that is, cultural homogeneity.

These divergences and convergences ultimately testify to how deeply intellectual property law is formed and moulded in connection with history. As such, it reflects both different patterns and stages of industrial development, legal tradition, culture, etc., as well as an increasing homogeneity in the prospects for technological advancement and eventual closer transnational economic integration.

\section{Bibliographical Notes}

A preliminary general overview of the historical evolution of intellectual (formerly: 'industrial' and 'intellectual') property law from its command-economy origins to a regulatory framework based on equal rights and duties for entrepreneurs (in the classical system, consumers' interests are indirectly protected: see Chapters 4 and 5 below) may be gleaned from a series of works that include: R. A. Spinello, M. BotTis, A Defense of Intellectual Property Rights, Cheltenham, 2009; W. VAN CAENEGEM, Intellectual Property Law and Innovation, Cambridge, 2007; C. MAY, S.K. SELL, Intellectual Property Rights - A Critical History, Boulder, 2006; P.A. DAVID, The Evolution of Intellectual Property Institutions, in A. Aganbegyan, O. Bogmolov and M. KASER (eds), System Transformations: Eastern and Western Assessments (Proceedings of the Tenth Congress of the International Economic Association), London, 1994; P.O. Long, Invention, Authorship, Intellectual Property, and the Origins of Patents: Notes Toward a Conceptual History, in Tech. and Culture, 1991, 846; W. Bugbee, The Genesis of American Patent and Copyright Law, Washington, DC, 1967. See also the classic work by E. PouILLET, Traité théorique et pratique des brévets d'invention et de la contrefaçon, Paris, 1909.

As recalled in the chapter, modern IP law was shaped to a large extent (not only at the level of the coordination and/or harmonisation of national legal frameworks, but also in terms of common substantive principles) by the ground-breaking international conventions of the late 1800s: the Paris Convention of 1883 on 'industrial property' and the Berne Convention of 1886 on copyright. These conventions marked the first structured response to the ever-increasing integration of the world's most industrialised economies, which was both symbolised and stimulated by the great 'Universal Exhibitions' at the turn of the century (see, among others, L. Aimone and C. Olmo, Le esposizioni universali 1851-1900: Il progresso in scena, Turin, 1990).

For an in-depth overview of these Conventions, see in particular the works by $\mathrm{J}$. GINSBURG and S. RICKETSON, International Copyright and Neighbouring Rights - The Berne Convention and Beyond, Oxford, 2005 and the essay by S. RICKETSON, The Berne Convention: The Continued Relevance of Ancient Text, in D. VAVER and L. BENTLY (eds), Intellectual Property in the New Millennium: Essays in Honour of William R. Cornish, Cambridge, 2004, 217; Y. Plasseraud and F. SAvignon, Paris 
1883: Genèse du droit unioniste des brevets, Paris, 1981. See also some older but quite well-structured and well-informed works: A. BoGSCH, The Law of Copyright under Universal Copyright Convention, Geneva, 1972; B.W. BugBeE, The Genesis of American Patent and Copyright Law, Washington, DC,1967, chapter II; R. LuZZATTO, La proprietà industriale nelle convenzioni internazionali, Milan, 1950; S.P. LADAS, The International Protection of Industrial Property, Cambridge, 1930. For a recent overview see G.B. Dinwoodie, International Intellectual Property: Law and Policy (with W. Hennessey, S. Perlmutter \& G. Austin), New York, 2008.

The progressive contamination and hybridisation among the principles that represented the classical regulatory dualism between 'industrial' (patents, trademarks) and 'intellectual' (copyright and neighbouring rights) property must be analysed through both general and specific works. In the former category, especially noteworthy are the works by W. CoRnIsH, Intellectual Property. Patents, Copyright, Trademarks and Allied Rights, London, 2007; L. BENTLY and B. SHERMAn Intellectual Property Law, Oxford, 2009; P. Torremans, Holyoak and Torremans Intellectual Property Law, Oxford, 2008; H.C. Hansen, Intellectual Property Law and Policy, Oxford, 2008. Among specific essays focused on that dualism and its contemporary crisis, attention should be given to A. KUR, A New Framework for Intellectual Property Rights Horizontal Issues, in IIC, 2004, 1; J.H. REICHMAN, Legal Hybrids between the Patent and Copyright Paradigms, in Columbia L. Rev., 1994, 2432; ID., Charting the Collapse of the Patent-Copyright Dichotomy: Premises for a Restructured International Intellectual Property System, in Cardozo Arts \& Entertainment L.J., 1995, 475; R.C. DREYFuss, A Wiseguy's Approach to Information Products: Muscling the Copyright and Patent into a Unitary Theory of Intellectual Property, in S. Ct. Rev., 1992, 195; H.J. CoHEN, Hybrids on the Borderline between Copyright and Industrial Property Law, in Rev. int. droit d'auteur, 1992, 75; J. WILEY, Copyright at the School of Patent, in Univ. Chicago L. Rev., 1991, 119 (further works are cited in the bibliographical notes to Chapters 2 and 3).

The evolution of overprotectionist trends in IP law to the point of reaching a veritable 'misappropriation explosion' (W.J. GoRDON, On Owning Information: Intellectual Property and the Restitutionary Impulse, in Va. L. Rev., 1992, 149), has been excellently described by J.H. REICHMAN in the works cited above as well as in Beyond the Historical Lines of Demarcation: Competition Law, Intellectual Property Rights, and International Trade after the Gatt's Uruguay Round, in Brooklin J. of Intern. L., 1993, 75. May I also quote my Prospettive 'protezioniste' nel diritto industriale, in Riv. dir. ind., 1995, I, 73.

This phenomenon of 'overprotectionism' is the result of the growing importance attached by major firms in the developed world to so-called intellectual asset management (IAM), that is, the exploitation of the monopolistic potential of intellectual property. For a summary, see O. GRANSTRAND, The Economics and Management of Intellectual Property - Towards Intellectual Capitalism, Cheltenham, UK, 1999; W. Anson, How Intangible Assets Drive Capitalization, in Les Nouvelles, 1999, 133; G. WINTER, Knowledge and Competence as Strategic Assets, in D.J. TEECE (ed.), The Competitive Challenge, Cambridge, MA, 1987). The drive towards such exploitation is in turn linked to short-term managerial business policies. More fundamentally, those 'overprotectionist' tendencies also reflect a much wider fabric of social processes and economic factors (which are not always rational: B. DEMIL and X. LECOCQ, Neither Market nor Hierarchy nor Network: The Emergence of Bazaar Governance, in Organization Studies, 2006, 1447). Those factors and processes have driven industrialised countries' economies towards oligopolistic settings, hence also steering the 
evolution of contemporary commercial law towards (what are basically) US-type paradigms. For a broad overview of said factors and processes, and their impact on the transnational legal framework, see J.E. STIGLITZ, Economic Foundations of Intellectual Property Rights, in 57 Duke L.J., 2008, I, 693; J. DREXL, Intellectual Property Rights as Constituent Elements of a Competition-based Market Economy, in Intellectual Property and Market Power, ATRIP Papers 2006-2007, Buenos Aires, 2008, 167; J.H. REICHMAN, Nurturing a Transnational System of Innovation, in 16 J. of Transnational L. \& Pol., 2007, 143; R. Dreyfuss, Preserving the Public Domain of Science in International Law, in KeITH E. MASKus and J.H. REICHMAN (eds) (with Graeme Dinwoodie), International Public Goods and Transfer of Technology under a Globalized Intellectual Property Regime, Cambridge, 2005; M. MATsushitA, T.J. Schoenbaum and P. Mavroidis, The World Trade Organization: Law, Practice and Policy, Oxford, 2006; M.A. LemLey, Property, Intellectual Property, and Free Riding, in Stanford Law and Economics, Olin Working Paper No. 291, 2004; S.K. SELL, Private Power, Public Law: The Globalization of Intellectual Property Rights, Cambridge, 2003; K.E. Maskus and J.H. ReICHMAN, The Globalization of Private Knowledge Goods and the Privatization of Global Public Goods, in Journal of International Economic Law, 2004, 279-320; J.R. OsTERGARD, The Development Dilemma: The Political Economy of Intellectual Property Rights in the International System, New York, 2002; S.D. ANDERMAN, EC Competition Law and Intellectual Property Rights in the New Economy, in 47 Antitrust Bulletin, 2002, 285; S. SASSEN, Losing Control?, New York, 1996; C.R. FRISCHTAK, Harmonization versus Differentiation in Intellectual Property Rights Regime, in M.B. WALLERSTEIN, M.E. MogeE and R.A. ScHoEn, (eds), Global Dimension of Intellectual Property Rights in Science and Technology, Washington, DC, 1993; D.M. TrubeK, Y.D. DEZALAY, R. BuChanAN and J.R. DAVIS, Global Restructuring and the Law: The Internalization of Legal Fields and Creation of International Arenas, I, Univ. Wisconsin, Madison, 1993.

On the role and impact of developed countries' IP protection models (as reflected by TRIPs) in the relationship of the said countries with those still developing, see the Appendix and the ensuing bibliographical note.

Reaction to overprotectionist tendencies has occurred, as hinted in the text, along two legal and policy dimensions. The first (above, sections 5-7 in this chapter), is an increased awareness of the link between protecting intellectual property and safeguarding competition (and consequently the interests of the consumers: see K.J. Cseres, Competition Law and Consumer Protection, The Hague, 2005; see also the bibliographical notes to Chapters 2, 3, 4 and 5 ). The second is the growing awareness, even among many business circles, that 'all-excludent' IP paradigms may hinder, rather than enhance, the pace of innovation and creativity in the contemporary 'knowledge economy' (above, section 11 in this chapter, and below Chapter 3). 